\title{
Neural Cell Adhesion Molecule-Mediated Fyn Activation Promotes GABAergic Synapse Maturation in Postnatal Mouse Cortex
}

\author{
Bidisha Chattopadhyaya, ${ }^{1}$ Elie Baho, ${ }^{1}$ Z. Josh Huang, ${ }^{2}$ Melitta Schachner, ${ }^{3,4}$ and Graziella Di Cristo ${ }^{1}$ \\ ${ }^{1}$ CHU Sainte Justine Research Center, University of Montreal, Montreal, Quebec H3T 1C5, Canada, ${ }^{2}$ Cold Spring Harbor Laboratory, Cold Spring Harbor, \\ New York 11724, ${ }^{3}$ Center for Molecular Neurobiology, University Medical Center Hamburg-Eppendorf, D-20246 Hamburg, Germany, and ${ }^{4}$ Department of \\ Cell Biology and Neuroscience and Keck Center for Collaborative Neuroscience, Rutgers University, Piscataway, New Jersey 08854-8082
}

GABAergic basket interneurons form perisomatic synapses, which are essential for regulating neural networks, and their alterations are linked to various cognitive dysfunction. Maturation of basket synapses in postnatal cortex is activity dependent. In particular, activitydependent downregulation of polysialiac acid carried by the neural cell adhesion molecule (NCAM) regulates the timing of their maturation. Whether and how NCAM per se affects GABAergic synapse development is unknown. Using single-cell genetics to knock out NCAM in individual basket interneurons in mouse cortical slice cultures, at specific developmental time periods, we found that NCAM loss during perisomatic synapse formation impairs the process of basket cell axonal branching and bouton formation. However, loss of NCAM once the synapses are already formed did not show any effect. We further show that NCAM120 and NCAM140, but not the NCAM180 isoform, rescue the phenotype. Finally, we demonstrate that a dominant-negative form of Fyn kinase mimics, whereas a constitutively active form of Fyn kinase rescues, the effects of NCAM knockdown. Altogether, our data suggest that NCAM120/NCAM140mediated Fyn activation promotes GABAergic synapse maturation in postnatal cortex.

\section{Introduction}

GABAergic interneurons form a diverse neuronal population that regulates and modulates overall network connectivity and activity (Somogyi et al., 1998; Markram et al., 2004; Somogyi and Klausberger, 2005; Kullmann, 2011). Fast-spiking, parvalbumin-positive basket cells constitute up to $50 \%$ of GABAergic interneurons in rodent cortex. In mature cortex, a single basket interneuron innervates hundreds of pyramidal neurons (Somogyi et al., 1998; Holmgren et al., 2003). At each postsynaptic target, a basket cell axon extends multiple terminals with large boutons clustered around pyramidal cell soma and proximal dendrites, forming the characteristic perisomatic synapses (Tamás et al., 1997). The mechanisms regulat-

\footnotetext{
Received March 16, 2012; revised Dec. 24, 2012; accepted Feb. 1, 2013.

Author contributions: B.C. and G.D.C. designed research; B.C. and E.B. performed research; Z.J.H. and M.S. contributed unpublished reagents/analytic tools; B.C. and E.B. analyzed data; B.C. and G.D.C. wrote the paper.

B.C. is supported by a Ste. Justine postdoctoral fellowship and the Savoy Foundation. G.D.C. has support from Canadian Institutes of Health Research, National Alliance for Research on Schizophrenia and Depression (Katowitz/ Radin Investigator), Natural Sciences and Engineering Research Council of Canada, Scottish Rite Charitable Foundation, Canada Foundation for Innovation and Canada Research Chair program. M.S. is New Jersey Professor of Spinal Cord Research. Z.J.H. is supported by the Robertson Neuroscience Fund at Cold Spring Harbor Laboratory. We thank Marisol Lavertu-Jolin for invaluable technical assistance. mRFP-tagged NCAM120, NCAM140, and NCAM180 isoforms were kind gifts from Dr. K. Hata and Dr. L. Landmesser (Case Western Reserve University, Cleveland, OH). Dr. P. Maness (University of North Carolina School of Medicine, Chapel Hill, NC) generously provided the FynDN and FynCA plasmids.

The authors declare no competing financial interests.

Correspondence should be addressed to Graziella Di Cristo, CHU Sainte Justine Research Center, University of Montreal, 3175 Cote-Ste-Catherine, Montreal, QC H3T 1C5, Canada. E-mail: graziella.dicristo@recherche.ste-justine.qc.ca.

DOI:10.1523/JNEUROSCI.1306-12.2013

Copyright $\odot 2013$ the authors $\quad 0270-6474 / 13 / 335957-12 \$ 15.00 / 0$
}

ing the formation of basket cell synapses are still not well understood.

The neural cell adhesion molecule (NCAM) and its polysialylated form (PSA-NCAM) have been implicated in several developmental process, including synapse maturation and stability at glutamatergic synapses and at the neuromuscular junction (Cremer et al., 1994, 1998; Rafuse and Landmesser, 1996; Rafuse et al., 2000). Recently, it has been shown that polysialic acid (PSA) acts as an activity-dependent signal to inhibit the formation of inhibitory synapses and the onset of ocular dominance plasticity in the developing visual cortex (Di Cristo et al., 2007). In addition to homophilic NCAM binding, PSA modulates multiple cell adhesion and signaling receptors, including cadherins, integrins (Fujimoto et al., 2001), FGF receptors (Dityatev et al., 2004; Ponimaskin et al., 2008; Chernyshova et al., 2011), and TrkB receptors (Muller et al., 2000; Kleene et al., 2010). Therefore, it is unknown whether, after the natural removal of PSA from NCAM, NCAM per se could continue to regulate GABAergic synapse maturation. Furthermore, NCAM exists in three alternatively spliced isoforms (Cunningham et al., 1987; Barbas et al., 1988): the 140 and 180 isoforms have intracellular domains differing only by a 267 aa insert in the 180 isoform, whereas the 120 isoform is glycosylphosphatidylinositol (GPI) linked and lacks an intracellular domain. Different NCAM isoforms play different roles in specific developmental processes (Polo-Parada et al., 2004; Hata et al., 2007). In addition, NCAM induces the activation of a number of intracellular signaling cascades (Maness and Schachner, 2007; Ditlevsen et al., 2008). It is so far unknown whether there is an isoform-specific effect on GABAergic synapse 
formation and, if so, what would be the signaling pathway involved in NCAM-mediated regulation of GABAergic synapses.

Using a single-cell genetic approach in organotypic cortical slices, we deleted NCAM in single basket interneurons at different developmental phases and studied its effect on perisomatic GABAergic innervation. We show that NCAM removal during basket cell maturation causes not only a significant decrease in perisomatic innervation around single pyramidal cell targets but also a significant reduction in the number of targeted postsynaptic pyramidal cells. In contrast, deletion of NCAM after basket synapse maturation does not affect basket cell innervation. Furthermore, we show that the NCAM120 and NCAM140, but not NCAM180, isoforms can rescue the deficits in perisomatic innervation caused by NCAM deletion and that they act through the downstream Fyn kinase signaling pathway to ensure appropriate maturation of basket cell perisomatic synapses.

\section{Materials and Methods}

$\mathrm{NCAM}^{\text {lox/lox }}$ transgenic mouse and DNA constructs. The NCAM ${ }^{\text {lox/lox }}$ transgenic mouse, wherein the fifth exon of the NCAM gene is flanked by two loxP sites, has been described previously (Bukalo et al., 2004). During biolistic transfection of organotypic slices from $N C A M^{\text {lox/lox }}$ mice of either sex, using the specific $\mathrm{P}_{\mathrm{G} 67}$ promoter driving Cre recombinase (Chattopadhyaya et al., 2007), the fifth exon was excised, resulting in knockdown of NCAM exclusively in GABAergic basket neurons.

All the monomeric red fluorescent protein (mRFP)-tagged NCAM120, NCAM140, and NCAM180 isoforms (generously provided by Drs. K. Hata and L. Landmesser, Case Western Reserve University, Cleveland, OH; Hata et al., 2007) and Fyn dominant-negative (DN) and constitutively active (CA) forms (generously provided by Dr. P. Maness, University of North Carolina School of Medicine, Chapel Hill, NC; Beggs et al., 1997) were cloned into the original $\mathrm{P}_{\mathrm{G} 67}-\mathrm{GFP}$ vector construct. $\mathrm{P}_{\mathrm{G} 67}-\mathrm{GFP}$ was generated by subcloning of a $10 \mathrm{~kb}$ region of Gad1 gene promoter by gap repair in front of the GFP coding region in pEGFP (Clontech) as described previously (Chattopadhyaya et al., 2004). The EGFP coding region was substituted with DNA fragment containing mRFP-NCAM120, mRFP-NCAM140, or mRFPNCAM1 80 or with Fyn DN or CA cDNA, respectively.

Slice culture and biolistic transfection. Slice culture preparation was essentially as described previously (Stoppini et al., 1991). Postnatal day 3 (P3) to P5 mice were decapitated, and brains were rapidly removed and immersed in culture medium (containing DMEM, 20\% horse serum, 1 mu glutamine, $13 \mathrm{~mm}$ glucose, $1 \mathrm{~mm} \mathrm{CaCl}, 2 \mathrm{~mm} \mathrm{MgSO}_{4}, 0.5 \mu \mathrm{m} / \mathrm{ml}$ insulin, $30 \mathrm{~mm}$ HEPES, $5 \mathrm{~mm} \mathrm{NaHCO}_{3}$, and $0.001 \%$ ascorbic acid). Coronal brain slices, $400 \mu \mathrm{m}$ thick, were cut with a chopper (Stoelting). Slices were then placed on transparent Millicell membrane inserts (Millipore), usually two to three slices per insert, in $30 \mathrm{~mm}$ Petri dishes containing $750 \mu \mathrm{l}$ of culture medium. Finally, they were incubated in a humidified incubator at $34^{\circ} \mathrm{C}$ with a $5 \% \mathrm{CO}_{2}$-enriched atmosphere, and the medium was changed three times per week. All procedures were performed under sterile conditions.

Constructs to be transfected were incorporated into "bullets" that are made using $1.6 \mu \mathrm{m}$ gold particles coated with 25-30 $\mu \mathrm{g}$ of each of the plasmids of interest. These bullets were used to biolistically transfect slices by gene gun (Bio-Rad) at high pressure $(180 \psi)$, and the transfected slices were incubated for $8 \mathrm{~d}$ at the time period of interest, under the same conditions as described above, before imaging.

Depending on the experiments, one to four constructs were coprecipitated onto gold particles. When a gold particle coated with multiple constructs enters the neuron, all the constructs are coexpressed within the same cell because they are all driven by $\mathrm{P}_{\mathrm{G} 67}$ promoter. For control cells, slices were labeled simply with $\mathrm{P}_{\mathrm{G} 67}-\mathrm{GFP}$ bullets, whereas for the NCAM knockdown cells, slices were transfected with double bullets containing $\mathrm{P}_{\mathrm{G} 67}-\mathrm{GFP}$ and $\mathrm{P}_{\mathrm{G} 67}-$ Cre or $\mathrm{P}_{\mathrm{G} 67}-\mathrm{GFP}-\mathrm{IRES}-\mathrm{Cre}$. For the rescue experiments, triple-coated bullets containing $\mathrm{P}_{\mathrm{G} 67}-\mathrm{GFP} / \mathrm{Cre}$ and one of $\mathrm{P}_{\mathrm{G} 67}-\mathrm{mRFP}-\mathrm{NCAM} 120, \mathrm{P}_{\mathrm{G} 67}-\mathrm{mRFP}-\mathrm{NCAM} 140$, or $\mathrm{P}_{\mathrm{G} 67}-\mathrm{mRFP}-$ NCAM180 were used. To study the role of Fyn kinase in NCAMmediated modulation of basket cell synapse formation, we used three types of bullets: (1) bullets coated with $\mathrm{P}_{\mathrm{G} 67}-\mathrm{GFP}$ and $\mathrm{P}_{\mathrm{G} 67}-\mathrm{FynDN}$; (2) bullets coated with $\mathrm{P}_{\mathrm{G} 67}-\mathrm{GFP} / \mathrm{CRE}$ and $\mathrm{P}_{\mathrm{G} 67}-$ FynCA; and (3) bullets coated with $\mathrm{P}_{\mathrm{G} 67}-\mathrm{GFP} / \mathrm{CRE}, \mathrm{P}_{\mathrm{G} 67}-\mathrm{mRFP}-\mathrm{NCAM} 120$, and $\mathrm{P}_{\mathrm{G} 67}-$ FynDN.

Immunohistochemistry, image acquisition, and analyses. Slices were fixed, freeze thawed, and immunostained as described previously (Chattopadhyaya et al., 2004). We used anti-NeuN, a monoclonal antibody that specifically labels neuronal nuclei (1:400; Millipore Bioscience Research Reagents), followed by incubation with either Alexa Fluor 555conjugated or Alexa Fluor 633-conjugated goat IgG (1:400; Invitrogen). All experiments were repeated at least three times. For each set of data, between 60 and 90 pyramidal innervated cell somata from at least six to nine basket cells were chosen for analysis. Analyzed basket cells were from at least four different animals, for each experimental group.

Non-overlapping fields of axonal innervation from well-isolated basket interneurons were acquired with a $63 \times$ glycerol-immersion objective (numerical aperture 1.4; Leica) using a confocal microscope (LEICA TCS SPE) (for example stacks, see videos of Chattopadhyaya et al., 2004, their Supplemental Data). $Z$-stacks were acquired with $1 \mu \mathrm{m}$ steps of at least 30 $\mu \mathrm{m}$ along the $z$-axis, exported as TIFF files, and analyzed with Neurolucida software (MicroBrightField). Green and red channels were separated, and basket axons and boutons were traced in three-dimensions in the green channel, which were then superimposed on the red channel containing images of pyramidal cell soma (identified by NeuN immunofluorescence). Care was taken to analyze only those pyramidal cell somata that were complete and well isolated. The following parameters were analyzed for each basket cell: (1) perisomatic bouton density; (2) axonal terminal branching around contacted somata; and (3) percentage of pyramidal somata contacted by basket cells. In our three-dimensional Sholl analysis, Sholl spheres with a $1 \mu \mathrm{m}$ increment from the center of a pyramidal soma were used to quantify basket axon terminal branch complexity and bouton density around the pyramidal cell soma. Axon branch complexity around a single pyramidal cell soma was quantified as the average number of intersections between basket cell axons and the Sholl spheres in the first $9 \mu \mathrm{m}$ from the center of the pyramidal cell soma. We choose $9 \mu \mathrm{m}$ as the limiting radius for a Sholl sphere because it approximates the average pyramidal cell soma radius measured from pyramidal neurons immunostained with NeuN antibody. Bouton density around each pyramidal cell soma was measured within the same set of Sholl spheres and averaged among pyramidal neurons for each condition. Only pyramidal cell somata with Sholl spheres, which intersect basket axons in the first $9 \mu \mathrm{m}$ from the center of their soma, were taken for analysis. Between 10 and 15 pyramidal neurons located not more than $200 \mu \mathrm{m}$ from the soma were analyzed for each basket cell. By using this method, we obtained an unbiased estimate of the number of presumptive boutons within a given distance of a labeled pyramidal cells soma (NeuN profiles), because we did not manually chose the boutons that contact the target. However, the functional status of these structures was not tested.

The percentage of pyramidal somata innervated by basket cells was defined in a confocal stack by the number of somata contacted by the basket cell axon divided by the total number of observed somata. This was repeated over all the fields of each basket axon, and the results were averaged.

Statistical analyses. Differences between multiple groups were assessed with one-way ANOVA, followed by the Holm-Sidak test for normally distributed data or the Dunn's test on ranks for not normally distributed data. Differences between two groups were assessed with the Student's $t$ test for normally distributed data and the Mann-Whitney $U$ test for not normally distributed data.

\section{Results \\ NCAM regulates synapse density and axon branching during basket cell development}

Germ-line homozygous deletion of the NCAM gene results in several developmental defects, including alterations in precursor migration, mossy fiber organization, and synaptic transmission and plasticity (Cremer et al., 1994, 1998). Because of the broad expression of NCAM in the nervous system and the concomitant 
lack of PSA in NCAM null mice, it has been not possible so far to pinpoint the specific role of NCAM in GABAergic synapse development. To examine the role of NCAM in the postnatal maturation of GABAergic inhibitory circuits in visual cortex, we used a transgenic mouse carrying a conditional allele of NCAM (Bukalo et al., 2004), which allows cell type and developmental stage restricted knockdown of NCAM synthesis. In this floxed NCAM mouse $\left(N C A M^{l o x / l o x}\right)$, Cre-mediated recombination results in excision of exon 5 , causing a shift in reading frame and termination of translation (Fig $1 A$ ).

To inhibit NCAM expression in basket interneurons and simultaneously label their axons and synapses, we used a previously characterized promoter region $\left(\mathrm{P}_{\mathrm{G} 67}\right.$; Chattopadhyaya et al., 2004) to express either Cre recombinase together with GFP $\left(\mathrm{P}_{\mathrm{G} 67}-\mathrm{GFP} / \mathrm{Cre}\right)$ or GFP alone in parvalbumin-positive basket interneurons in organotypic cultures from the visual cortex of $N C A M^{l o x / l o x}$ mice (Fig $1 A$ ). Previous studies have shown that the basic features of maturation of perisomatic innervation by basket interneurons onto pyramidal cells are retained in visual cortical organotypic cultures (Chattopadhyaya et al., 2004; Di Cristo et al., 2004). In organotypic cultures, basket interneurons start out with very sparse and simple axons, which develop into complex, highly branched arbors in the subsequent 4 weeks with a time course similar to that observed in vivo (Chattopadhyaya et al., 2004). We focused our study in the third and fourth week during which a significant and stereotyped maturation of perisomatic innervation occurs (Chattopadhyaya et al., 2004, 2007; Di Cristo et al., 2007). Furthermore, PSA expression is strongly reduced within the first 2 postnatal weeks in visual cortex (Di Cristo et al., 2007; Bélanger and Di Cristo, 2011); thus, inducing Cremediated recombination after this time point allows us to study the specific role of NCAM per se in GABAergic synapse maturation.

After NCAM deletion in single basket cells, we quantified two aspects of basket cell axon innervation: (1) the extent of perisomatic innervation around single somata (terminal branching and perisomatic synapse density); and (2) perisomatic innervation in the network (the fraction of innervated somata). We showed previously that the vast majority of GFP-labeled boutons in our experimental condition most likely represent presynaptic terminals (Chattopadhyaya et al., 2004, 2007; Wu et al., 2012). Using the analyses described in Materials and Methods, we obtained an unbiased estimate of the number of presumptive boutons on individual labeled pyramidal cell soma.

In age-matched basket cells from NCAM ${ }^{\text {lox/lox }}$ cultures transfected with $\mathrm{P}_{\mathrm{G} 67}-\mathrm{GFP} / \mathrm{Cre}$ (referred to here on as $\mathrm{NCAM}^{-/-}$ cells) from equivalent postnatal day 16 (EP16; P4 + $12 \mathrm{~d}$ in vitro) to EP24, the shape and gross branching pattern of axon arbors appeared similar to that of control cells (Fig 1B1,C1). Furthermore, $N C A M^{-1-}$ basket cell axons appeared thinner, bore fewer boutons around pyramidal cell somata (Fig 1, NeuN profiles, in red), and showed reduced number of terminal branches throughout the innervation field (Fig 1B2,C2,D,F; boutons/soma \pm SEM, $9.1 \pm 0.8$ for control vs $5.8 \pm 0.2$ for $N_{C A M}{ }^{-/-}$cells; Mann-Whitney $U$ test, $p<0.01)$. In addition, when comparing the fraction of innervated cells over the total number of potential targets in a confocal stack, we found a significant reduction of the percentage of innervated cells from each $N C A M^{-/-}$basket cell compared with controls (Fig. $1 E$; percentage of innervation \pm SEM, $50.2 \pm 0.4 \%$ for $N_{C A M^{-1-}}$ and $74 \pm 2 \%$ for controls; Mann-Whitney $U$ test, $p<0.01$ ). Together, these results suggest that NCAM per se regulates the number of potential targets contacted by a basket cell and the extent of perisomatic innervation established onto each contacted cell, during the maturation of GABAergic circuits (Fig 1G,H).

\section{NCAM120 and NCAM140 isoforms rescue perisomatic synapse maturation in $\mathrm{NCAM}^{-/-}$basket cells}

NCAM exists in three major alternatively spliced isoforms: the 140 and 180 isoforms have intracellular domains differing only by a 267 aa insert in the 180 isoform, whereas the 120 isoform is GPI linked and lacks an intracellular domain (Cunningham et al., 1987; Barbas et al., 1988). To explore whether different NCAM isoforms play different roles in basket cell synapse maturation, we inactivated the endogenous NCAM alleles and simultaneously reintroduced each mRFP-tagged NCAM isoform separately in single basket cells from EP16 to EP24. All three $\mathrm{P}_{\mathrm{G} 67}-\mathrm{mRFP}-$ NCAM isoforms were expressed to comparable levels in basket cells.

Surprisingly, both NCAM140 and NCAM120 were able to significantly rescue the deficits in perisomatic innervation caused by NCAM deletion in single basket cells. NCAM ${ }^{-/-}$basket cells expressing either mRFP-NCAM140 or mRFP-NCAM120 formed perisomatic innervations characterized by multiple terminal axon branches and clustered boutons that were indistinguishable from age-matched controls cells (compare Fig. 2A2,B2 with $1 B 2$ ) and were significantly different from $N C A M^{-/-}$basket cells (Fig. 2D, F; boutons/soma \pm SEM, $8.7 \pm 0.7$ for NCAM120 and $7.6 \pm 0.8$ for NCAM140 vs $5.8 \pm 0.2$ for $N C A M^{-/-}$basket cells; one-way ANOVA, $p<0.05)$. Similarly, $N C A M^{-/-}$basket cells expressing either mRFP-NCAM140 or mRFP-NCAM120 contacted a percentage of pyramidal cell somata in each confocal stack comparable with control cells (Fig. 2E; $70 \pm 2$ and $59 \pm 7 \%$, respectively, for NCAM120- and NCAM140-expressing $N_{C A M}{ }^{-1-}$ cells vs $74 \pm 2 \%$ for NCAM control basket cells; oneway ANOVA, $p>0.05)$. Overall, the rescue phenotype in $N_{C A M}{ }^{-1-}$ cells via NCAM120 expression was very consistent, whereas NCAM140 expression showed slightly more variability in its rescue effects. Interestingly, perisomatic bouton density (Fig. 2D; boutons/soma $\pm \mathrm{SEM}, 5.3 \pm 0.2$ ), terminal branch complexity (Fig. $2 F$ ), and the percentage of innervated somata (Fig. $2 E ; 38 \pm 3 \%$; one-way ANOVA, $p>0.05$ ) were not significantly different between mRFP-NCAM180-expressing $N C A M^{-1-}$ basket cells and $N C A M^{-/-}$basket cells (one-way ANOVA, $p>0.05)$. Altogether, these data demonstrate that NCAM120 and NCAM140, but not the NCAM180 isoform, are potentially able to promote the maturation of GABAergic basket cell innervation.

\section{Fyn kinase signaling mediates the effect of NCAM120 and NCAM140 isoforms on perisomatic synapse maturation} The ability of NCAM120 to rescue perisomatic GABAergic synapse maturation was unexpected, because NCAM120 lacks an intracellular domain and its signaling pathway is not well known. Recent data suggest that NCAM140 and NCAM180 differ in their ability to activate the Fyn-FAK kinase pathway (Niethammer et al., 2002), with NCAM140 being the most effective. In parallel, NCAM120 has been shown to be tightly associated with Fyn kinase in lipid rafts (Krämer et al., 1999). Therefore, we hypothesized that Fyn kinase pathway acts downstream to NCAM140 and NCAM120 and that its activation is necessary and sufficient for basket cell axon branching and bouton formation. To test this hypothesis, we used two experimental strategies: we transfected cultures from $N C A M^{l o x} / l o x$ mice from EP16 to EP24 with (1) a DN form of Fyn ( $\mathrm{P}_{\mathrm{G} 67}-\mathrm{FynDN}$ ) (Bodrikov et al., 2005) together with GFP or (2) with a CA form of Fyn ( $\mathrm{P}_{\mathrm{G} 67}-$ FynCA) (Bodrikov et al., 
A

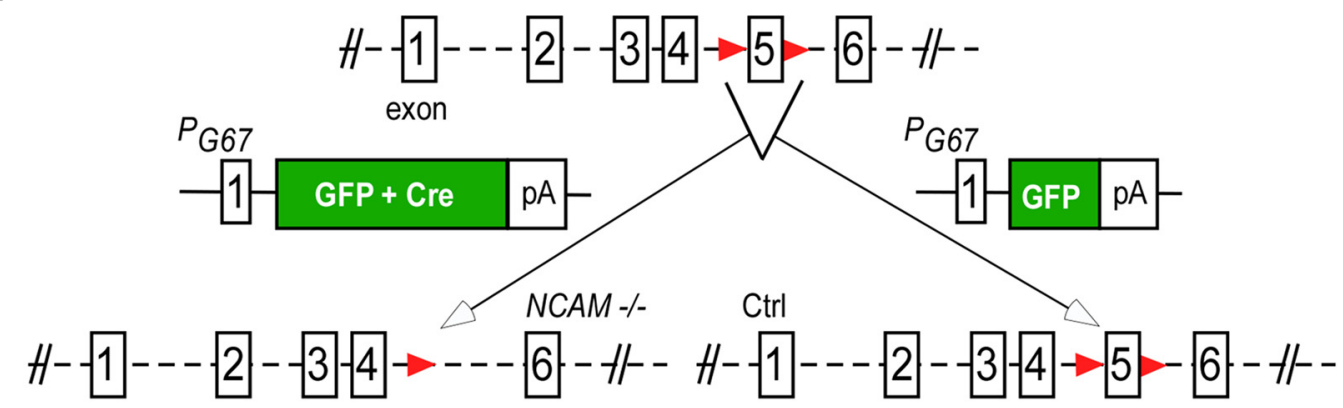

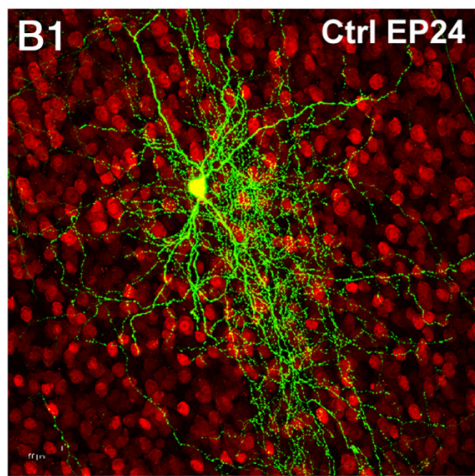
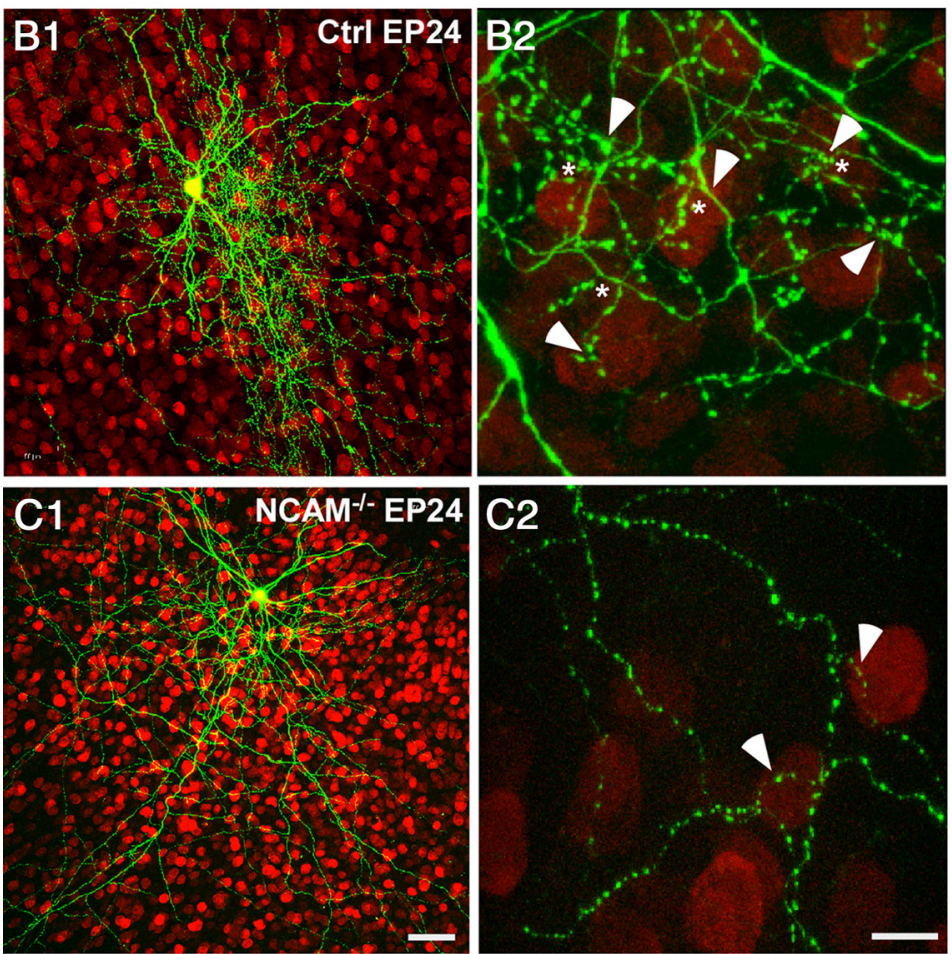

D Bouton Density

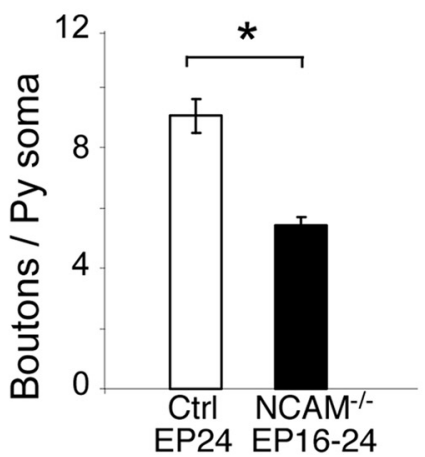

E \% Py innervated

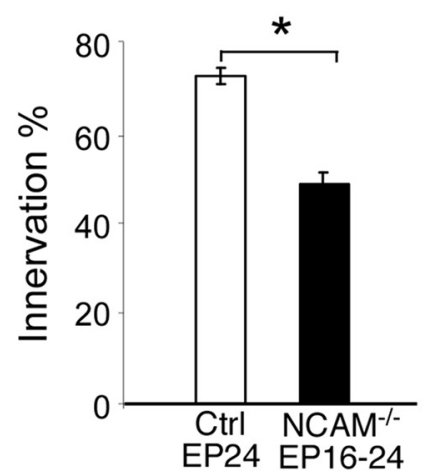

G Network Level

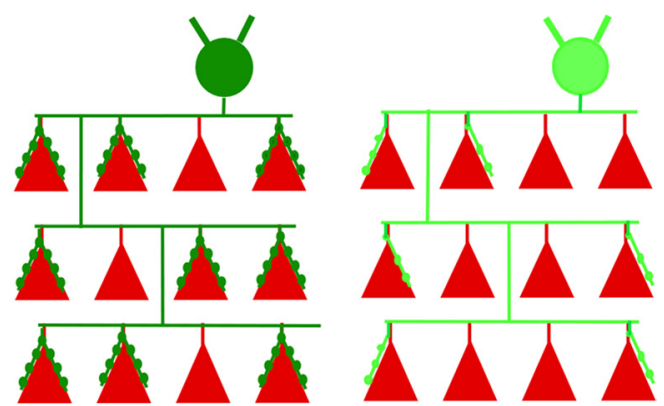

$\mathrm{H}$

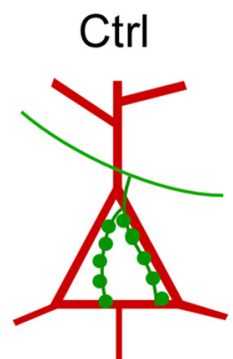

Terminal Branching

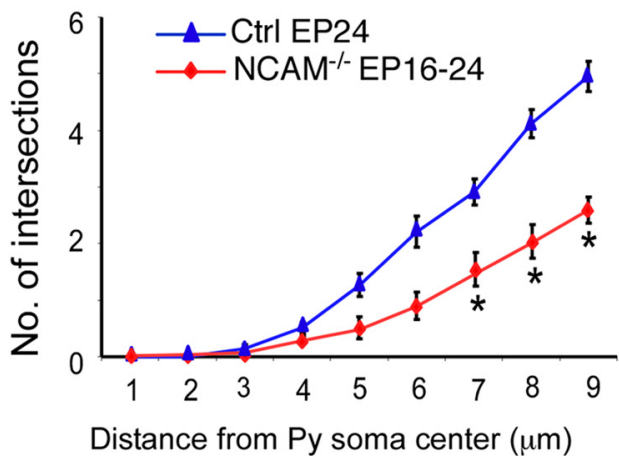

Figure 1. NCAM-deficient basket interneurons show reduced perisomatic innervation number and complexity. $A$, Exon 5 of the NCAM genewas flanked with loxP sites to create a conditional NCAM lox allele. Cortical organotypic cultures were transfected with biolistics with $\mathrm{P}_{667}-\mathrm{GFP}-\mathrm{IRES}$-Cre to generate NCAM-null (NCAM ${ }^{-/}$) or $\mathrm{P}_{667}-\mathrm{GFP}$ control (Ctrl) basket cells. B1, A control basket neuron (green) among other NeuN immunostained neurons (red). B2, Higher-magnification image of the control basket cell shows characteristic exuberant branching (asterisk) and numerous boutons (arrowheads) on the postsynaptic somata. C1, Conversely, an NCAM ${ }^{-1-}$ basket neuron has a markedly simple axon (C2), making fewer synapses (arrowheads) onto the postsynaptic somata. Scale bars: B1, C1, $30 \mu \mathrm{m} ; \mathbf{B 2}, \mathbf{C 2}, 10 \mu \mathrm{m} . \mathbf{D}$, $\boldsymbol{E}, \boldsymbol{F}$, Significant decrease in bouton density $(\boldsymbol{D})$, innervation percentage $(\boldsymbol{E})$, and complexity of terminal branching $(\boldsymbol{F})$ was found for $N C A M^{-1-}$ basket neurons compared with control cells $($ Mann-Whitney $U$ test, $\left.{ }^{*} p<0.01\right) . n=7$ control basket cells; $n=11 \mathrm{NCAM}^{-1-}$ basketneurons. Error bars represent the average \pm SEM. $\mathbf{G}, \boldsymbol{H}$, Schematic diagram showing that NCAM knockdown in basket neurons significantly affects the total number of somata it innervates at the network level $(\boldsymbol{G})$ and reduces the number of contacts at the level of individual postsynaptic targets $(\boldsymbol{H})$. Py, Pyramidal. 

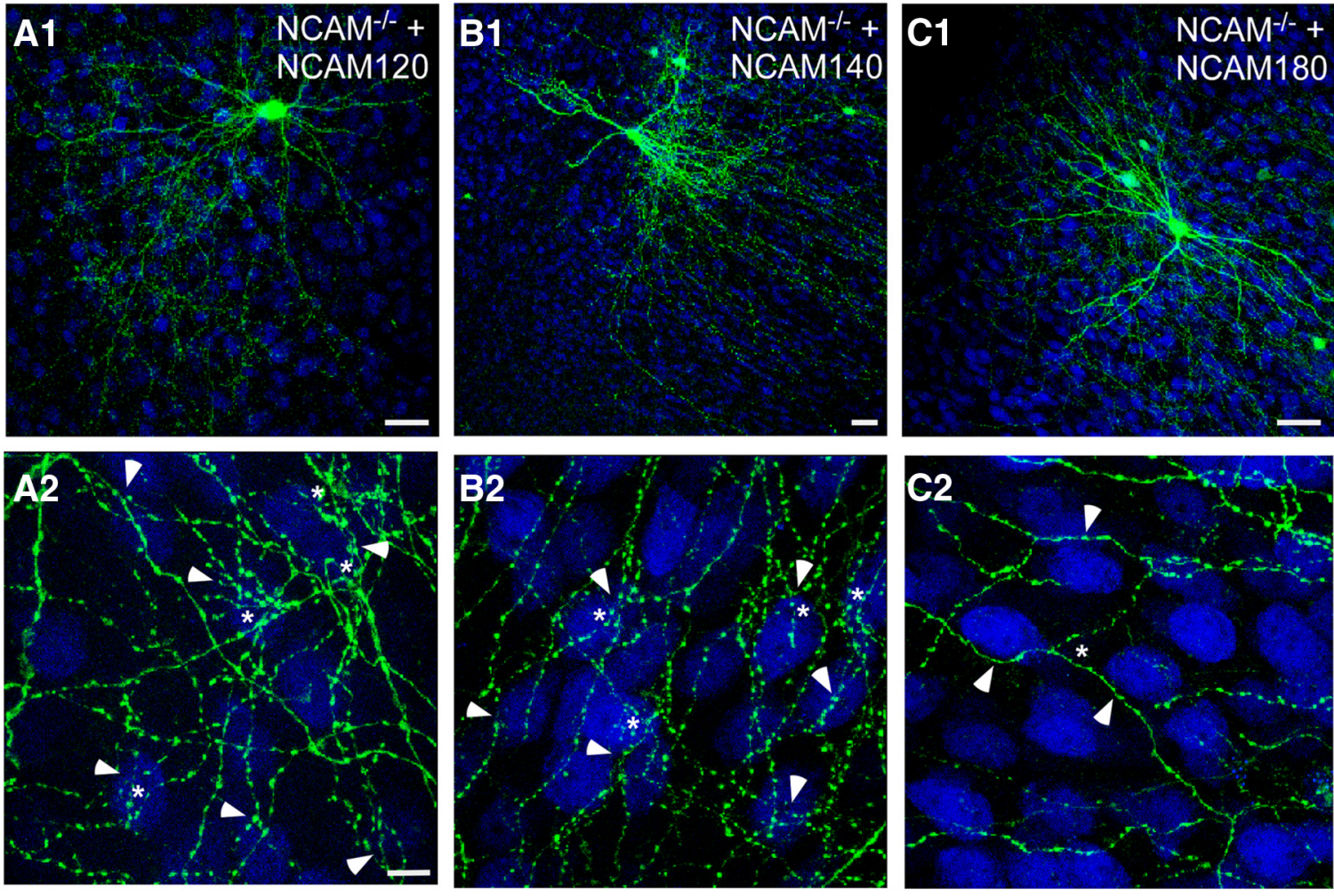

D Bouton Density

E \% Soma innervated

F Terminal Branching
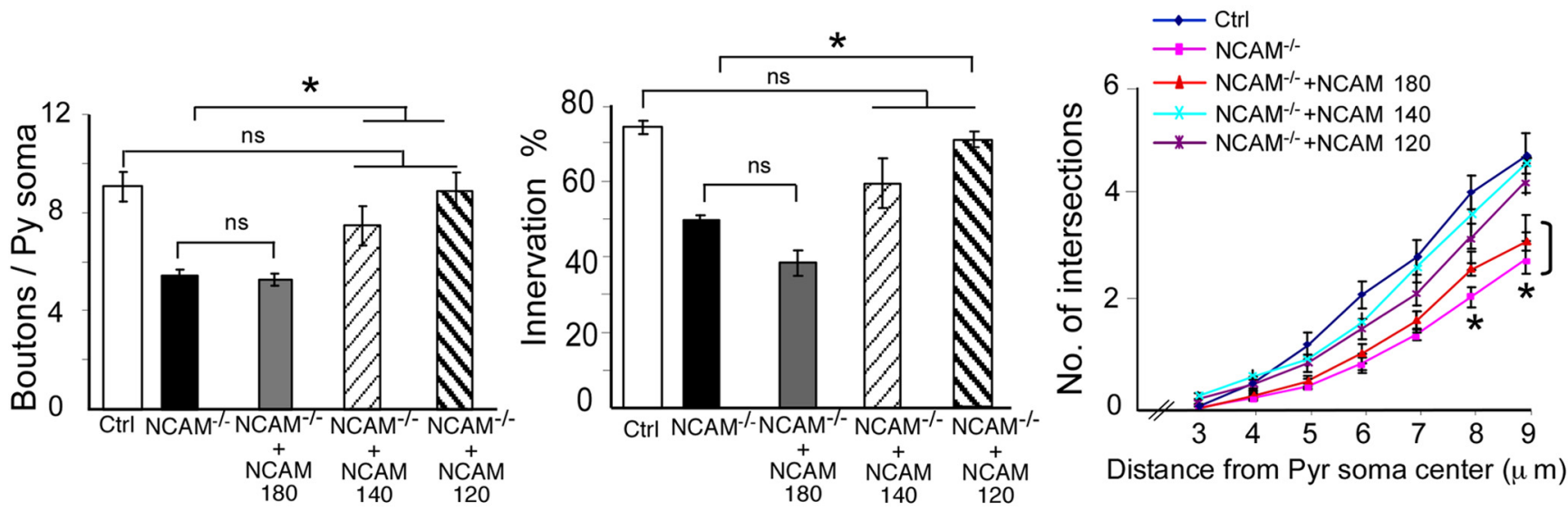

Figure 2. Coexpression of NCAM120 and NCAM140 but not the NCAM180 isoform rescue perisomatic innervation deficits in $N C A M^{-/-}$basket cells. $A, B, N C A M^{-/-}$basket cells cotransfected with $\operatorname{NCAM120}(\boldsymbol{A 1}, \boldsymbol{A 2})$ or NCAM140 (B1, B2) isoform show the characteristic terminal branching (asterisk) and numerous contacts (arrowheads) onto postsynaptic NeuN immunolabeled (blue) somata. C1, C2, However, $N C A M^{-1-}$ basket neurons cotransfected with NCAM180 exhibit simple axons with few synaptic contacts onto their postsynaptic targets. Scale bars: A1, B1, C1, $20 \mu \mathrm{m} ; A \mathbf{A 2}, \mathbf{B 2}$, $\left(2,10 \mu \mathrm{m} . \boldsymbol{D}-\boldsymbol{F}\right.$, Quantitative morphological analysis shows that NCAM ${ }^{-1-}$ basket neurons cotransfected with either NCAM120 or NCAM140 isoform have bouton density (D), innervation density $(\boldsymbol{E})$, and terminal branching $(\boldsymbol{F})$ comparable with controls (one-way ANOVA, post hoc Dunn's test, $p>0.05$ ) and significantly different from NCAM ${ }^{-\prime-}$ basket neurons (one-way ANOVA, post hoc Dunn's test, ${ }^{*} p<0.01$ ). Conversely, $N C A M^{-\prime-}$ basket neurons cotransfected with NCAM180 isoform show no difference compared with NCAM ${ }^{-1-}$ basket cell in any of the parameters analyzed

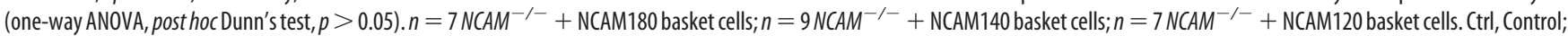
Py, pyramidal.

2005) together with Cre/GFP. We reasoned that reducing endogenous levels of Fyn activity should mimic the effect NCAM deletion in wild-type basket cells, whereas a CA form of Fyn should rescue the effects of NCAM deletion in $N C A M^{-1-}$ basket cells. Consistent with our hypothesis, wild-type basket cells transfected with FynDN from EP16 to EP24 contacted less pyramidal cells, showed reduced axon branching, and formed a lower number of boutons around pyramidal somata compared with control basket cells, whereas they were indistinguishable from $N C A M^{-1-}$ basket cells (Fig. 3A,D-F; boutons/soma \pm SEM, $5.9 \pm 0.2$ for FynDN- expressing basket cells vs $9.1 \pm 0.8$ and $5.8 \pm 0.2$ for controls and $N C A M^{-1-}$ basket cells, respectively; percentage of innervation \pm SEM, $50 \pm 3 \%$ for FynDN-expressing cells vs $74 \pm 2$ and $50.2 \pm 0.4 \%$ for controls and $N C A M^{-1-}$ basket cells, respectively). Conversely, FynCA overexpression was sufficient to rescue the bouton density around each innervated soma and the percentage of somata innervated by $N C A M^{-/-}$basket cell innervation to control levels (Fig. $3 B, D, E$; boutons/soma $\pm \mathrm{SEM}$, $9.1 \pm 0.2$ for FynCA-expressing $N C A M^{-1-}$ basket cells vs $9.1 \pm$ 0.8 for control basket cells; percentage of innervation \pm SEM, 

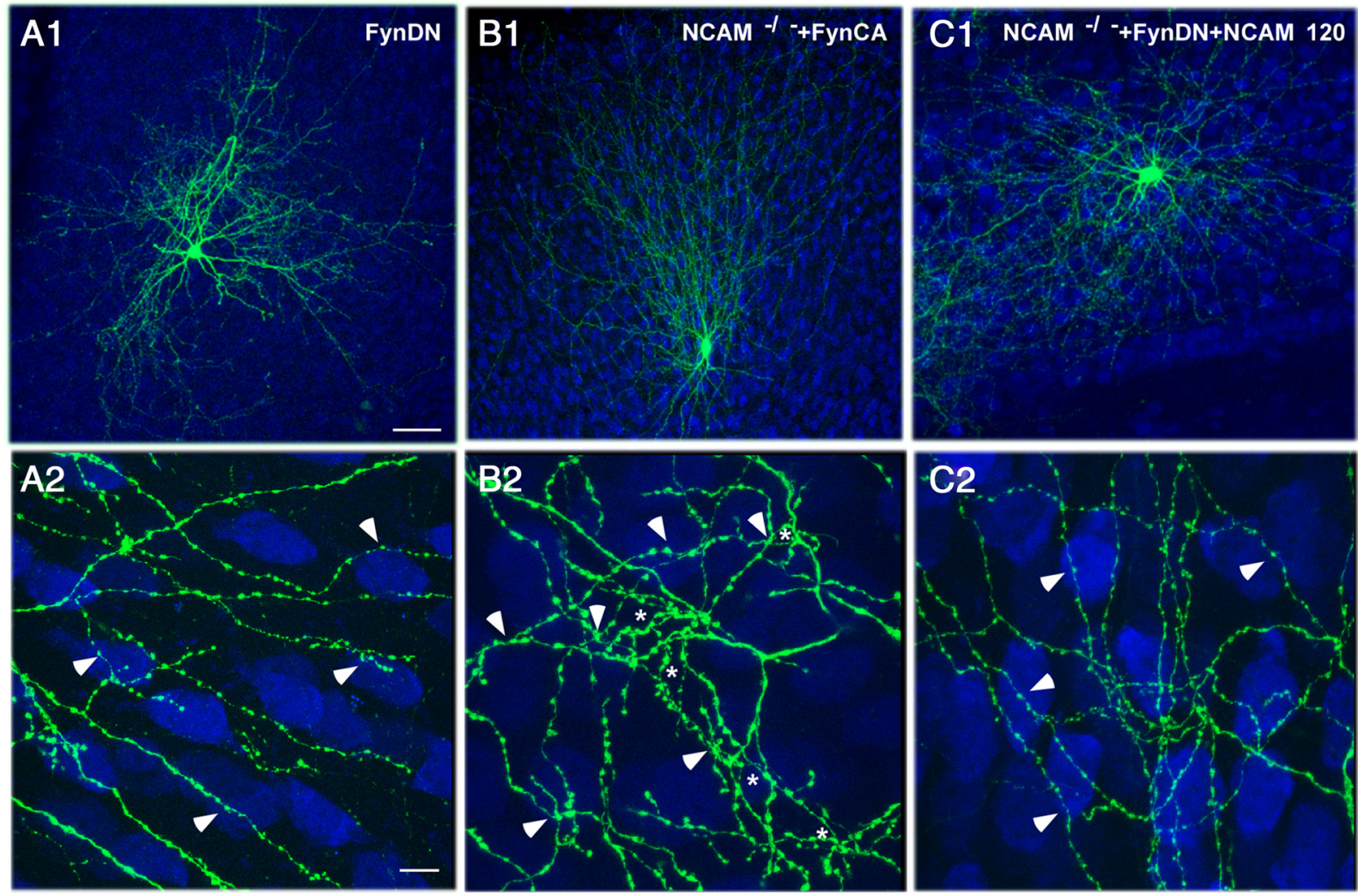

\section{Bouton Density}

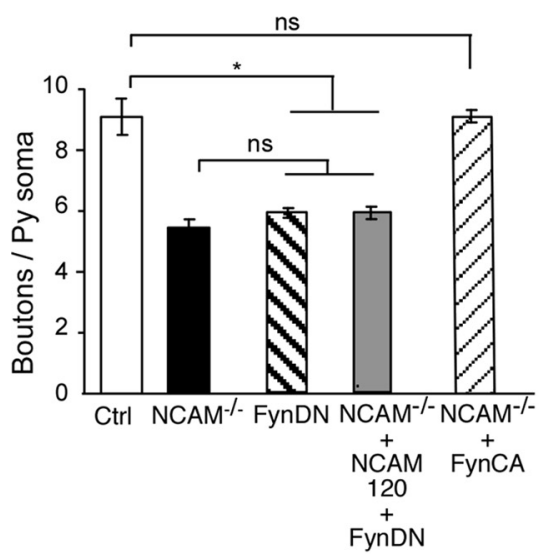

E \% Soma innervated

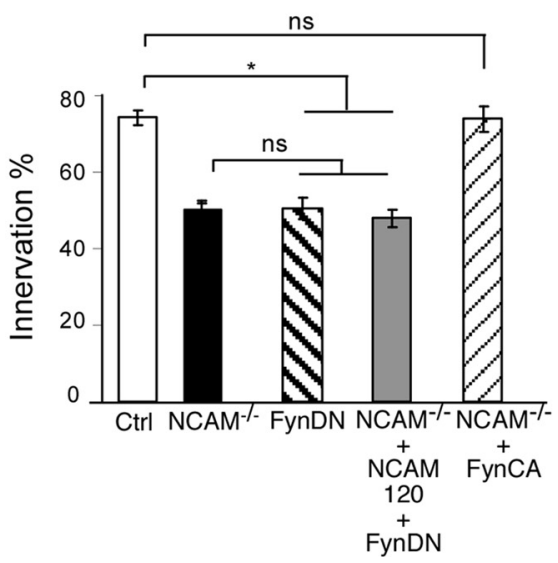

\section{F Terminal Branching}

Figure 3. Fyn kinase activity mediates the effect of NCAM on perisomatic synapse maturation. $\mathbf{A 1}$, A2, Transfection of FynDN in wild-type basket cells from EP16 to EP24 causes deficits in perisomatic axon branching and synaptic contacts ( $\boldsymbol{A} 2$, arrowheads) similar to what is observed in $N C A M^{-1-}$ basket cells. $\boldsymbol{B} \mathbf{1}, \boldsymbol{B 2}, N C A M^{-1-}$ basket neurons transfected with FynCA regain the ability to form complex perisomatic synapses similar to the rescue effects of NCAM120 and NCAM140 isoforms; asterisks indicate terminal branching, and arrowheads indicate perisomatic synapses. $\mathbf{C 1}, \mathbf{C 2}$, Cotransfection of FynDN with NCAM120 isoform blocks NCAM120 rescue effects, and innervation remains poor compared with controls. Scale bars: $\mathbf{A 1}, \mathbf{B 1}, \mathbf{C 1}, 30 \mu \mathrm{m} ; \boldsymbol{A 2}, \mathbf{B 2}, \mathbf{C 2}, 10 \mu \mathrm{m}$. $\boldsymbol{D}-\boldsymbol{F}$, Bouton density $(\boldsymbol{D})$, innervation percentage $(\boldsymbol{E})$, and terminal branching $(\boldsymbol{F})$ characteristics are not significantly different between $N C A M^{-/-}$basket cells, FynDN transfected $N C A M^{+/+}$basket cells, or NCAM ${ }^{-1-}$ basket cells transfected with FynDN + NCAM120 (one-way ANOVA, post hoc Dunn's test, $p>0.05$ ). Conversely, bouton density and percentage of innervated targets are significantly higher in FynCA-expressing NCAM ${ }^{-/-}$basket cells compared with NCAM ${ }^{-/-}$basket cells (one-way ANOVA, post hoc Dunn's test, ${ }^{*} p<0.01$ ). $n=6 N C A M^{+/+}+$FynDN basket cells; $n=6 N C A M^{-1-}+$ FynCA basket cells; $n=7 N C A M^{-1-}+$ NCAM120 + FynDN basket cells. Ctrl, Control; Pyr, pyramidal.

$74 \pm 3 \%$ for FynDN-expressing cells vs $74 \pm 2$ for controls). However, the axon of $\mathrm{NCAM}^{-1-}$ basket cells expressing FynCA formed less terminal branching around innervated somata compared with controls (Fig. $3 F$ ) and harbored dense boutons that appeared notably more variable in shape and size. It is possible that the CA form of Fyn kinase might not be subjected to the same tight temporal and spatial regulation as endogenous Fyn activity, resulting in premature stabilization of contacts between the axon and the postsynaptic cell, which may impair the growth of terminal axon branching and result in an excess formation of boutons. Alternatively, NCAM may be needed for the local activation of other signaling molecules in addition to Fyn kinase, which could in turn promote terminal branching formation.

Finally, if Fyn kinase activation acts downstream to NCAM120 in regulating the development of basket cell innervation, then coexpressing FynDN and NCAM120 in the same 
$N C A M^{-1-}$ basket interneuron should block the rescue effects of NCAM120. To test this hypothesis, we biolistically transfected the constructs $\mathrm{P}_{\mathrm{G} 67}-\mathrm{GFP} / \mathrm{Cre}, \mathrm{P}_{\mathrm{G} 67}-\mathrm{FynDN}$, and $\mathrm{P}_{\mathrm{G} 67}-$ NCAM120 in single basket cells. $N C A M^{-/-}$basket cells cotransfected with both FynDN and NCAM120 were overall indistinguishable from $N C A M^{-/-}$basket cells or wild-type basket cells expressing FynDN alone (Fig. 3C--F). NCAM ${ }^{-1-}$ basket cells cotransfected with both FynDN and NCAM120 showed a reduction in axon density, perisomatic bouton density, and percentage of innervated cells compared with $\mathrm{NCAM}^{-/-}$basket cells expressing NCAM120 alone (compare Fig. $3 C$ with $2 A$; boutons/ soma \pm SEM, $5.9 \pm 0.2$ and percentage of innervation \pm SEM, $48 \pm 2 \%$ for $N_{C A M}{ }^{-/-}$basket cells expressing both NCAM120 and FynDN vs $8.7 \pm 0.7$ and $70 \pm 2 \%$, respectively, for $N C A M^{-1-}$ basket cells expressing NCAM120 alone). These results suggest that NCAM-mediated activation of Fyn kinase plays a major role in the maturation of the innervation field of basket GABAergic cells in postnatal cortex.

To further investigate the link between different NCAM isoforms and Fyn signaling, we expressed $\mathrm{P}_{\mathrm{G} 67}$-FynCA together with GFP in either presence of endogenous NCAM levels or in $\mathrm{NCAM}^{-/-}$basket cells expressing $\mathrm{P}_{\mathrm{G} 67}-\mathrm{NCAM} 180$ alone. $N C A M^{-1-}$ basket cells cotransfected with both FynCA and NCAM180 show normal bouton density and percentage of innervation compared with control basket cells (Fig. 4A, C,D; boutons/soma \pm SEM, $8.2 \pm 0.2$ for $N C A M^{-1-}$ basket cells expressing both FynCA and NCAM180 vs $9.1 \pm 0.8$ for control basket cells; percentage of innervation \pm SEM, $59 \pm 4 \%$ for FynCA/NCAM180-expressing cells vs $74 \pm 2 \%$ for controls; oneway ANOVA, $p>0.05)$. However, the axon of $N C A M^{-/-}$basket cells expressing FynCA/NCAM180 formed slightly less terminal branching around innervated somata compared with controls, a result similar to $\mathrm{NCAM}^{-/-}$basket cells expressing only FynCA (Fig. 4E; one-way ANOVA, $p<0.05$ ), whereas $N C A M^{+/+}$basket cells expressing FynCA (Fig. $4 B$ ) or $N C A M^{-/-}$expressing FynCA and NCAM120 (data not shown) form terminal branching indistinguishable from control cells (Fig. 4E; one-way ANOVA, $p>$ $0.05)$. Interestingly, $N C A M^{+/+}$basket cells expressing FynCA form a slightly, but significantly, higher number of perisomatic boutons around targeted pyramidal cells compared with controls or NCAM ${ }^{-1-}$ basket cells expressing both NCAM180 and FynCA (boutons/soma \pm SEM, $11.7 \pm 0.9$ for FynCA-expressing $\mathrm{NCAM}^{+/+}$basket cells vs $9.1 \pm 0.8$ for $\mathrm{NCAM}^{+/+}$basket cells and $8.2 \pm 0.2$ for $N C A M^{-/-}$basket cells expressing both FynCA and NCAM180; one-way ANOVA, $p<0.05$ ). This is consistent with the fact that FynCA overexpression can rescue perisomatic bouton number in $N C A M^{-/-}$cells or $N C A M^{-1-}$ expressing NCAM180, without fully rescuing terminal branching. This maybe because either (1) overexpression of FynCA prematurely stabilizes the basket cell perisomatic boutons, influencing terminal axon branching or (2) parallel pathways other than Fyn kinase that are triggered by NCAM can also promote terminal branching. Altogether, these data strengthen the conclusion that NCAM120/NCAM140 but not NCAM180, are needed for the proper maturation of GABAergic basket cell synaptic field, through the local activation of Fyn kinase and possibly other signaling molecules.

\section{NCAM is not necessary for the maintenance of basket cell perisomatic synapses}

To examine whether NCAM was continuously required to maintain the extensive basket cell axon arbors and perisomatic innervation, we inactivated both NCAM alleles in basket interneurons from EP26 to EP32, after the mature innervation pattern had been established (Chattopadhyaya et al., 2004). NCAM ${ }^{-/-}$ showed no differences in overall axon morphology, terminal axon branching, bouton number around pyramidal cell somata, and percentage of contacted targets compared with age-matched controls (Fig. 5A,B,D-F; boutons/soma \pm SEM, $10.3 \pm 0.9$ for $N C A M^{-/-}$vs $10.3 \pm 0.5$ for control basket cells; one-way ANOVA, $p>0.05)$. Moreover, overexpression of FynDN in wildtype basket cells from EP26 to EP32 had no detectable effects on the overall basket cell innervation compared with controls (Fig. $5 C, D--F$; boutons/soma \pm SEM, $10.3 \pm 0.4$; one-way ANOVA, $p>0.05)$. Altogether, these data suggest that NCAM-mediated Fyn activation is not necessary for the structural maintenance of the basket interneuron perisomatic innervation.

\section{Discussion}

The formation of mature GABAergic innervation is established during an extended postnatal period. In particular, the increase of exuberant local axon branching and perisomatic innervation is most pronounced between postnatal weeks 3 and 4, concurrent with the maturation of functional GABAergic inhibition (Morales et al., 2002; Chattopadhyaya et al., 2004). Here we show that NCAM expression in a single GABAergic basket cell is necessary for the maturation of its innervation. Moreover, we show that NCAM140 and NCAM120, but not NCAM180, can mediate this effect, partly through Fyn kinase activation.

\section{NCAM regulates the maturation but not the maintenance of perisomatic GABAergic innervation formed by individual basket cells}

Studying the effect of NCAM is complicated by the multiple roles it plays during different stages of development (Doherty et al., 1990a,b; Bronner-Fraser et al., 1992), (Rafuse et al., 2000; PoloParada et al., 2004), (Dityatev et al., 2004; Sytnyk et al., 2006; Puchkov et al., 2011). Mice with constitutive disruption of the NCAM gene show several morphological and functional changes, including reduction in the size of the olfactory bulb, disrupted lamination in CA3 region of the hippocampus, impaired spatial memory and learning, and increased aggressive behavior (Cremer et al., 1994, 1998; Stork et al., 1997, 1999). Another level of complexity is added by the fact that NCAM is the main carrier of PSA. In fact, transgenic mice unable to synthetize PSA show a more drastic phenotype than NCAM knock-out mice, likely because of a gain of NCAM function at the wrong developmental stages (Weinhold et al., 2005; Hildebrandt et al., 2007, 2010). By using the Cre-loxP recombination system to generate single, isolated basket cells in which NCAM is ablated, we could dissect out the role of NCAM in the maturation of perisomatic GABAergic innervation from other developmental effects. In addition, we could restrict genetic deletion to specific stages of GABAergic cell axon and synapse development, when PSA expression is already reduced (Di Cristo et al., 2007), thereby circumventing any earlier developmental consequence of NCAM knock-out and PSA reduction. We found that NCAM deletion impairs drastically the increase in their perisomatic synapse density and terminal branching observed between EP16 and EP24. It remains to be determined whether wild-type basket cells innervating the same pyramidal cells as the $N C A M^{-/-}$ones form more synapses around each target, resulting in overall unchanged perisomatic synapse density.

An open question is whether NCAM is involved in the initial formation of synaptic connectivity or whether it plays a role mainly in the subsequent steps of synapse proliferation, mainte- 

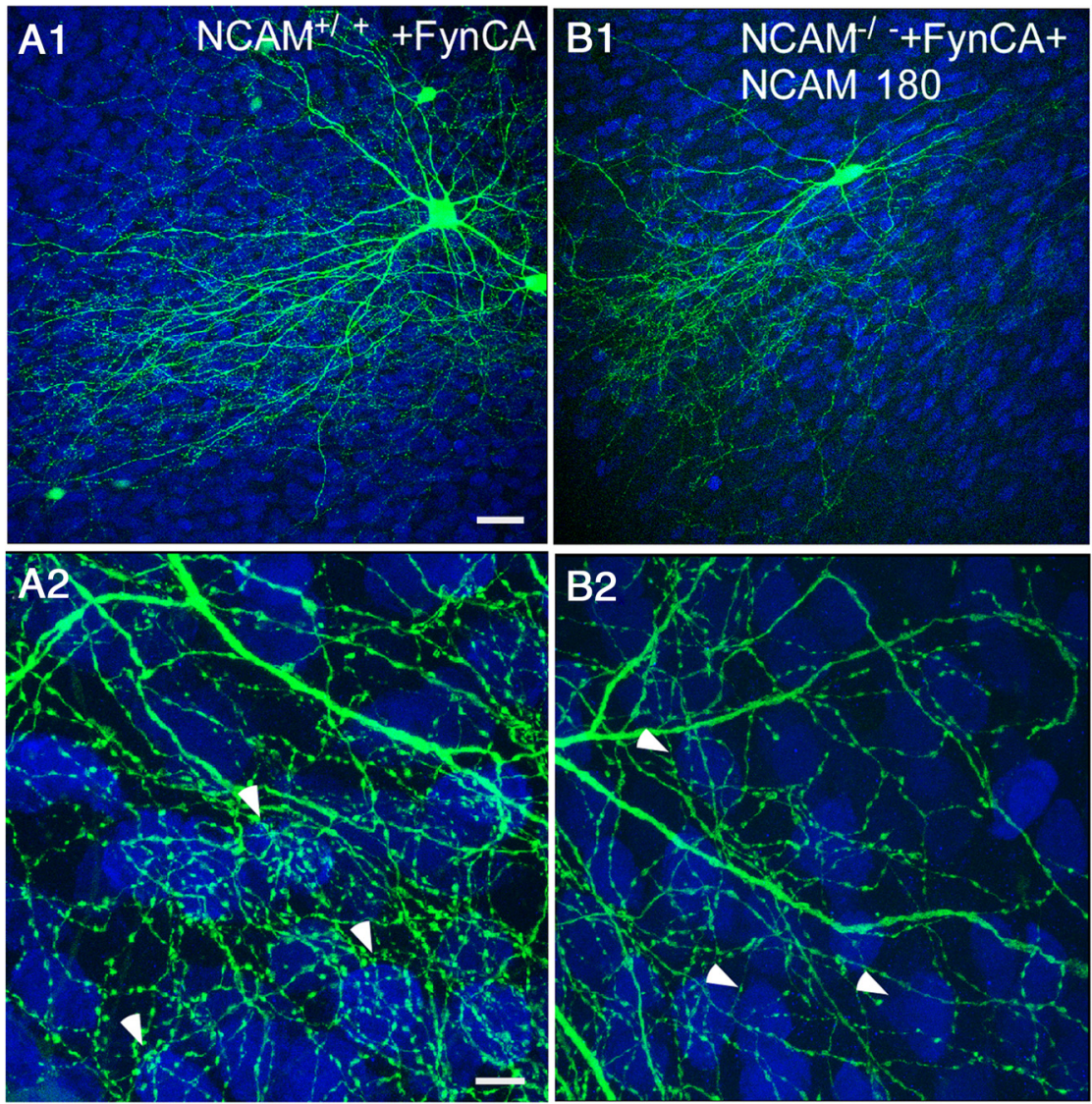

C Bouton Density

D \% Soma innervated

E

Terminal Branching
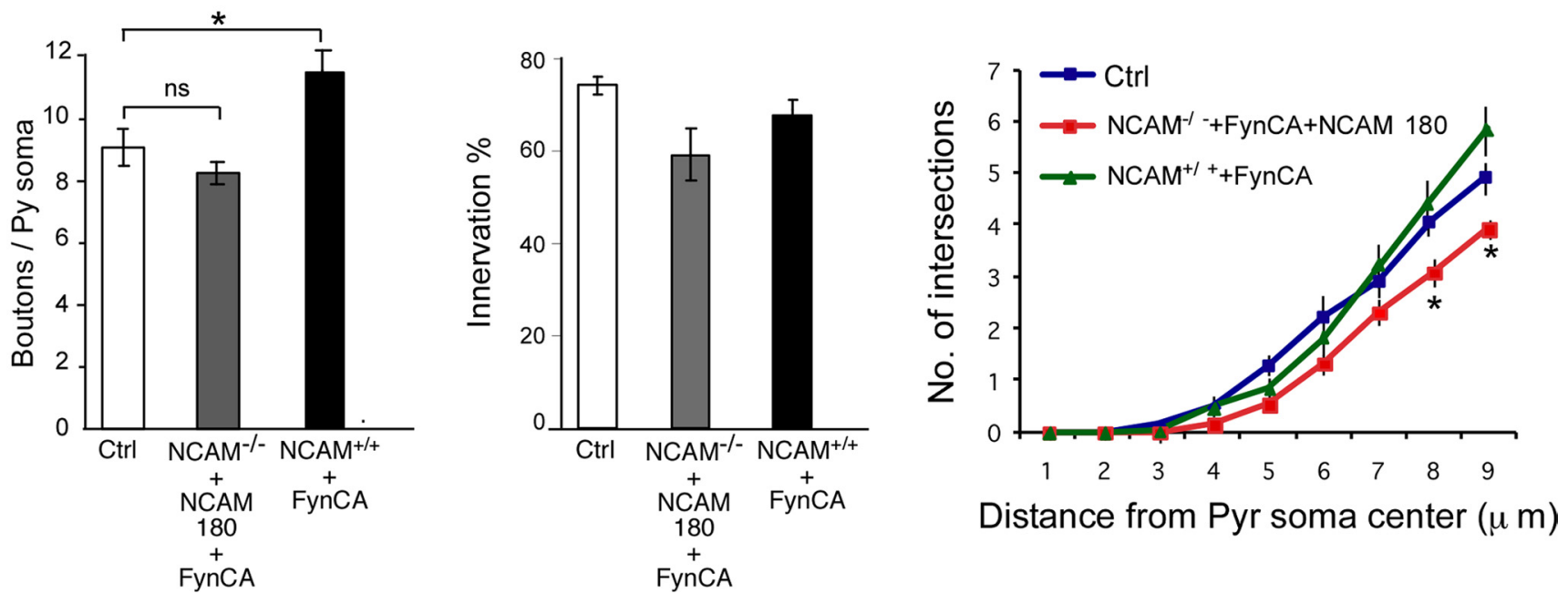

Figure 4. Coexpression of NCAM180 with the CA form of Fyn kinase rescues perisomatic synapse formation to the same extent as the CA Fyn kinase alone. $A, B, N C A M^{+/+}$basket cells cotransfected with FynCA $(\boldsymbol{A 1}, \boldsymbol{A} \mathbf{2})$ form richer terminal branching compared with NCAM ${ }^{-1-}$ basket cells cotransfected with FynCA and NCAM180 isoform $(\boldsymbol{B 1}, \boldsymbol{B} 2)$ around postsynaptic NeuN immunolabeled (blue) somata (arrowheads indicate examples of perisomatic innervation formed by the basket cell). Scale bars: $\boldsymbol{A 1}, \boldsymbol{B 1}, 20 \mu \mathrm{m} ; \boldsymbol{A 2}, \boldsymbol{B 2}, 10 \mu \mathrm{m}$. $\mathbf{C}-\boldsymbol{E}$, Bouton density (C) and innervation percentage $(\boldsymbol{D})$ are not significantly different between $N C A M^{-1-}$ basket cells coexpressing FynCA + NCAM180 and control basket cells (one-way ANOVA, post hoc Dunn's test, ${ }^{*} p>$ 0.05 ), whereas terminal branching $(\boldsymbol{E})$ is significantly reduced (one-way ANOVA, ${ }^{*} p<0.05$ ). Bouton density is slightly higher in $N C A M^{+/+}$basket cells expressing Fyn CA compared with control cells (one-way ANOVA, $\left.{ }^{*} p<0.05\right) . n=9$ control basket cells; $n=5 \mathrm{NCAM}^{+/+}+$FynCA basket cells; $n=5 \mathrm{NCAM}{ }^{-1-}+$ FynCA + NCAM180 basket cells. Ctrl, Control; Pyr, pyramidal.

nance, and plasticity. In mice lacking NCAM, neuromuscular junctions form but display characteristics of an immature junction (Rafuse et al., 2000; Polo-Parada et al., 2001), supporting a critical role for NCAM in the organization and maturation of the presynaptic site. In addition, NCAM and its polysialylated form regulate the ability of the postsynaptic density to undergo remodeling in the CNS (Muller et al., 2010). Our data show that NCAM deletion during the phase of perisomatic GABAergic synaptic maturation drastically impairs this process, whereas NCAM knock-out at a later stage, when perisomatic synapses have 

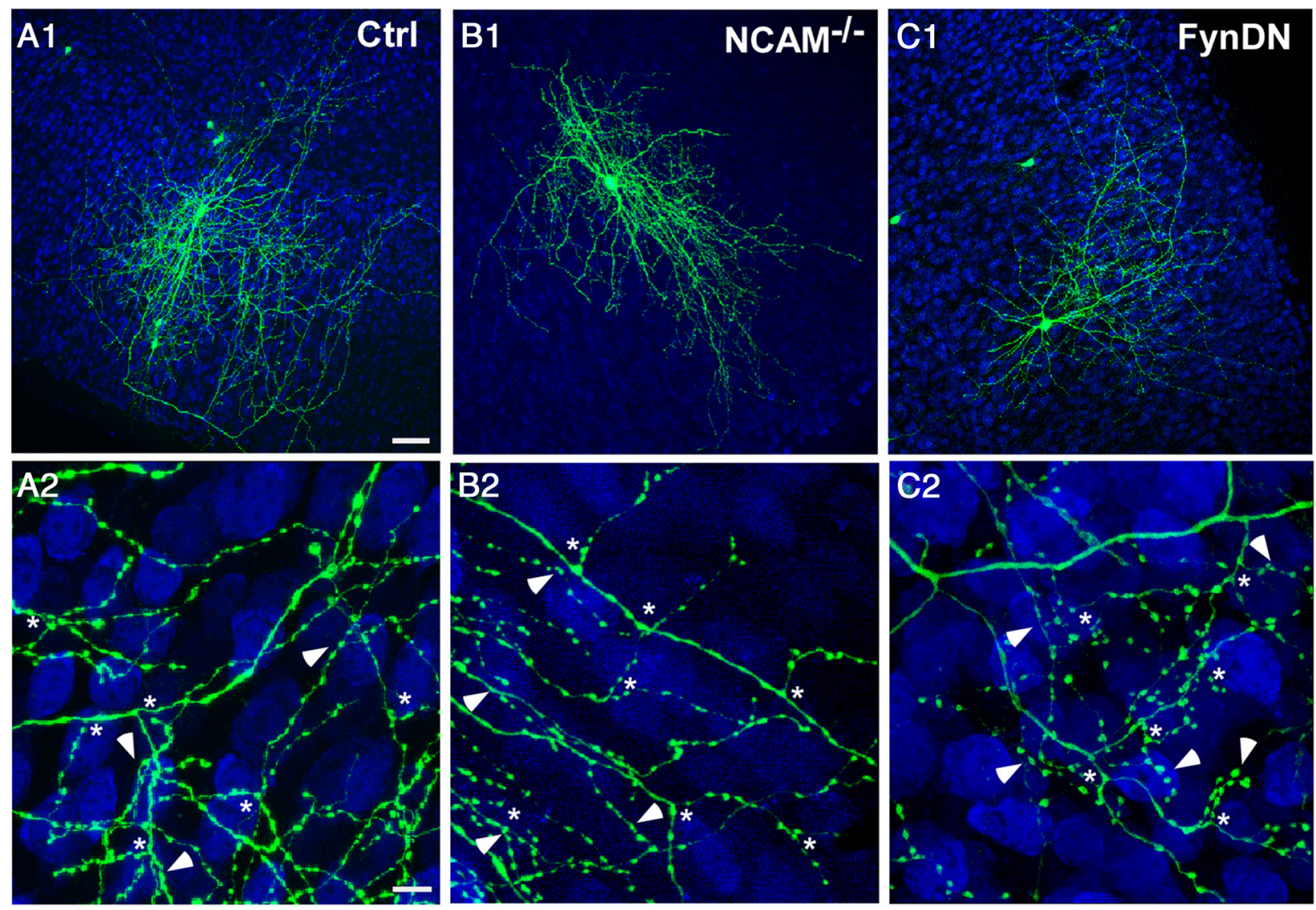

\section{Bouton Density}

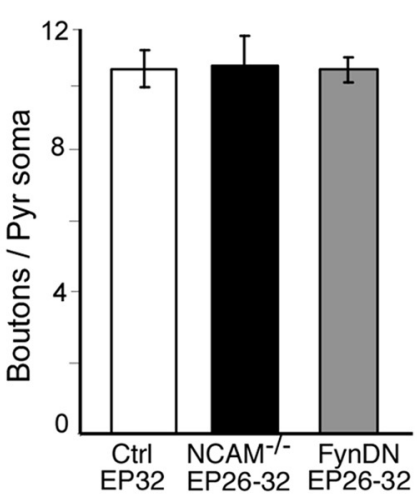

E \% Soma innervated

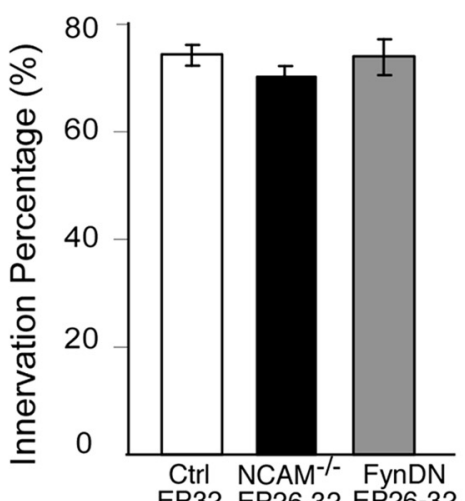

EP32 EP26-32 EP26-32
F Terminal Branching

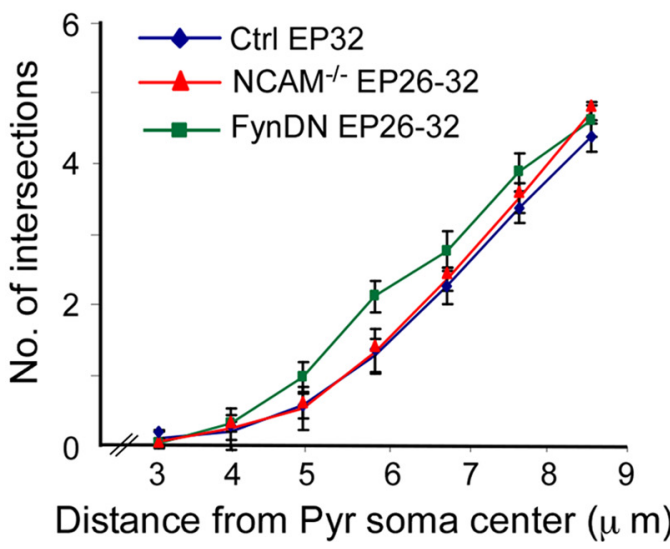

Figure 5. NCAM is not required for the maintenance of perisomatic basket cell synapses. $\boldsymbol{A} 1-\mathbf{C} 2$, Control $(\boldsymbol{A} 1, \boldsymbol{A 2}), N C A M^{-1-}(B \mathbf{B}, \mathbf{B 2})$, and $N C A M^{+/+}(C 1, C 2)$ basket cells transfected with FynDN from EP26 to EP32 show similar exuberant branching (A2, B2, C2; asterisk) and perisomatic synapses (A2, B2, C2; arrowheads). Scale bars: $\boldsymbol{A 1}, \boldsymbol{B} 1, \mathbf{C} 1,50 \mu \mathrm{m} ; \boldsymbol{A 2}, \mathbf{B 2}, \mathbf{C 2}, 10 \mu \mathrm{m} . \mathbf{D}-\boldsymbol{F}$, Bouton density $(\boldsymbol{D})$, innervation percentage $(\boldsymbol{E})$, and terminal branching complexity $(\boldsymbol{F})$ are not significantly different between the three groups (one-way ANOVA, post hoc Dunn's test, $p>0.05$ ). $n=7$ control basket cells; $n=8 \mathrm{NCAM}^{-/-}$basket neurons; $n=6 \mathrm{NCAM}^{+/+}+$FynDN basket cells. Ctrl, Control; Pyr, pyramidal.

reached their mature morphology, does not seem to have an effect. One possibility is that NCAM at the mature synapse is more stable, maybe as part of a complex with other synaptic proteins. If this was the case, waiting $8 \mathrm{~d}$ after knocking out the NCAM gene may not be long enough to see a reduction of NCAM protein levels at the synapse. However, transfection of a DN form of Fyn kinase, which should reduce Fyn activity as soon as it is expressed, impairs NCAM-mediated perisomatic GABAergic synapse maturation but not their maintenance, therefore supporting the conclusion that NCAM plays a specific role during
GABAergic synapse proliferation. However, we cannot at this stage exclude that NCAM reduction at later stages might affect different aspects of GABAergic physiology and plasticity.

NCAM120 and NCAM140, but not NCAM180, overexpression rescues the effect of NCAM deficit via Fyn kinase activation In the CNS, NCAM140 is localized to migratory growth cones and axon shafts of developing neurons, whereas NCAM180 is predominantly expressed in neurons late in development and is enriched in the postsynaptic densities of mature neurons 
(Persohn et al., 1989). NCAM120 was originally thought to be expressed mainly in glia (Noble et al., 1985), but it was later shown to be enriched in lipid rafts extracted from growth cones from the postnatal brain (He and Meiri, 2002) and from isolated forebrain synaptosomes (Korshunova et al., 2007).

Here, we showed that NCAM140 and NCAM120, but not the NCAM1 80 isoform, are able to rescue NCAM gene deletion. The ability of NCAM120 to rescue perisomatic GABAergic synapse maturation was an unexpected result, because NCAM120 lacks an intracellular domain and both its downstream signaling pathway and role in neurons are less known. Our results suggest that NCAM120 effects are mediated by Fyn activity, because coexpression of NCAM120 and a DN form of Fyn blocks the rescue effects of NCAM120 on perisomatic GABAergic synapse formation in $N C A M^{-1-}$ basket cells (Fig. 4).

It has been shown that palmitoylation of the intracellular domain of NCAM140 and NCAM180 promotes dynamic redistribution of NCAM to lipid rafts in which they activate distinct downstream signal transducing proteins (Niethammer et al., 2002). Although NCAM180 and NCAM140 are localized in both membrane subcompartments, only lipid-raft-associated NCAM140 is able to activate the Fyn-FAK kinase pathway (Niethammer et al., 2002). In contrast to NCAM140 and NCAM180, NCAM120 is constitutively associated with lipid rafts, in which it is tightly associated with Fyn kinase (Krämer et al., 1999). GPI-linked molecules, such as NCAM120 can cause productive interactions with Fyn kinase by clustering in rafts, thereby activating ERK1/2 (Krämer et al., 1999; Crossin and Krushel, 2000). Indeed, it has been proposed that rafts can promote low-affinity "kiss-and-run" interactions attributable to locally enriched concentrations of interacting molecules. Alternatively, activation of intracellular kinases by GPI-anchored NCAM120 may depend on cis-interactions with transmembrane molecules (Zeng et al., 1999).

\section{Role of Fyn kinase in GABAergic synapse development}

We propose that Fyn activity lies at the center of NCAM regulation of GABAergic synapse maturation because a DN form of Fyn impairs GABAergic synapse maturation, whereas a CA form primarily rescues the effect of NCAM knockout. NCAM-mediated Fyn activation may in turn locally regulate other factors that are important for GABAergic synapse development. For example, Fyn regulates neurofascin distribution, which in turn localizes GABAergic innervation by basket cells to the axon initial segment of Purkinje cells (Ango et al., 2004). Fyn also binds to and phosphorylates the $\gamma 2$ subunit of the $\mathrm{GABA}_{\mathrm{A}}$ receptor, which is thought to result in rapid recruitment of $\mathrm{GABA}_{\mathrm{A}}$ receptors to postsynaptic sites in neurons (Jurd et al., 2010). Furthermore, during BDNF activation, TrkB receptors are selectively recruited to lipid raft membranes through a mechanism that involves Fyn (Pereira and Chao, 2007). Inhibiting TrkB translocation to lipid rafts, by using either Fyn knock-out neurons or lipid-raftdisturbing agents, prevents the full activation of TrkB, therefore affecting the outcome of BDNF signaling. BDNF signaling is well known to promote GABAergic synapse maturation (Huang et al., 1999). Interestingly, TrkB can also directly bind to NCAM and modulate NCAM-mediated signaling via tyrosine phosphorylation (Cassens et al., 2010). Finally, NCAM, together with TrkB, regulates the surface expression of the inwardly rectifying $\mathrm{K}^{+}$ channel subunit Kir3.3, which in turn has important roles in the modulation of membrane potential and excitability of neurons (Kleene et al., 2010).
Altogether, our data suggest that local NCAM-mediated Fyn activation may, alone or in concert with other adhesion molecules, ion channels, and neurotrophic factors, start a positive feedback mechanism to accelerate GABAergic synapse maturation once PSA has been removed by neural activity and sensory experience.

\section{NCAM implication in neurodevelopmental diseases}

A growing body of evidence has implicated NCAM as a susceptible risk for neuropsychiatric disorders with neurodevelopmental origin, such as schizophrenia and depressive and anxiety disorders (Brennaman and Maness, 2010). Although these disorders vary in symptoms, age of onset, treatment, and neuronal systems affected, they share cognitive dysfunction as a core feature. In parallel, several studies point to a central and causal role of GABAergic deficits in the etiology of schizophrenia and depressive disorders (Lewis et al., 2005; Luscher et al., 2011). It is tantalizing to hypothesize that subtle alteration in NCAM signaling may change the developmental trajectory of GABAergic synapse maturation, therefore predisposing the individual to the occurrence of cognitive dysfunction.

In support of this hypothesis, disease severity and duration have been correlated with increased levels of a soluble fragment consisting of the extracellular domain of NCAM in the CSF, prefrontal cortex, and hippocampus of individuals with schizophrenia (Vawter et al., 2001). Transgenic mice overexpressing the NCAM extracellular proteolytic cleavage fragment show impaired GABAergic innervation and several behavioral alterations resembling schizophrenia traits (Pillai-Nair et al., 2005; Brennaman and Maness, 2010). Our study on perisomatic GABAergic synapses demonstrates that specific NCAM isoforms regulate the process of synapse maturation, which in turn is mediated by Fyn activation. Future studies will help us understand whether targeted manipulation of the NCAM pathway may help to alleviate cognitive problems in neurodevelopmental diseases.

\section{References}

Ango F, di Cristo G, Higashiyama H, Bennett V, Wu P, Huang ZJ (2004) Ankyrin-based subcellular gradient of neurofascin, an immunoglobulin family protein, directs GABAergic innervation at purkinje axon initial segment. Cell 119:257-272. CrossRef Medline

Barbas JA, Chaix JC, Steinmetz M, Goridis C (1988) Differential splicing and alternative polyadenylation generates distinct NCAM transcripts and proteins in the mouse. EMBO J 7:625-632. Medline

Beggs HE, Baragona SC, Hemperly JJ, Maness PF (1997) NCAM140 interacts with the focal adhesion kinase p125(fak) and the SRC-related tyrosine kinase p59(fyn). J Biol Chem 272:8310-8319. CrossRef Medline

Bélanger MC, Di Cristo G (2011) Sensory experience differentially modulates the mRNA expression of the polysialyltransferases ST8SiaII and ST8SiaIV in postnatal mouse visual cortex. PLoS One 6:e24874. CrossRef Medline

Bodrikov V, Leshchyns'ka I, Sytnyk V, Overvoorde J, den Hertog J, Schachner M (2005) RPTPalpha is essential for NCAM-mediated p59fyn activation and neurite elongation. J Cell Biol 168:127-139. CrossRef Medline

Brennaman LH, Maness PF (2010) NCAM in neuropsychiatric and neurodegenerative disorders. Adv Exp Med Biol 663:299-317. CrossRef Medline

Bronner-Fraser M, Wolf JJ, Murray BA (1992) Effects of antibodies against $\mathrm{N}$-cadherin and N-CAM on the cranial neural crest and neural tube. Dev Biol 153:291-301. CrossRef Medline

Bukalo O, Fentrop N, Lee AY, Salmen B, Law JW, Wotjak CT, Schweizer M, Dityatev A, Schachner M (2004) Conditional ablation of the neural cell adhesion molecule reduces precision of spatial learning, long-term potentiation, and depression in the CA1 subfield of mouse hippocampus. J Neurosci 24:1565-1577. CrossRef Medline

Cassens C, Kleene R, Xiao MF, Friedrich C, Dityateva G, Schafer-Nielsen C, Schachner M (2010) Binding of the receptor tyrosine kinase TrkB to the 
neural cell adhesion molecule (NCAM) regulates phosphorylation of NCAM and NCAM-dependent neurite outgrowth. J Biol Chem 285: 28959-28967. CrossRef Medline

Chattopadhyaya B, Di Cristo G, Higashiyama H, Knott GW, Kuhlman SJ, Welker E, Huang ZJ (2004) Experience and activity-dependent maturation of perisomatic GABAergic innervation in primary visual cortex during a postnatal critical period. J Neurosci 24:9598-9611. CrossRef Medline

Chattopadhyaya B, Di Cristo G, Wu CZ, Knott G, Kuhlman S, Fu Y, Palmiter RD, Huang ZJ (2007) GAD67-mediated GABA synthesis and signaling regulate inhibitory synaptic innervation in the visual cortex. Neuron 54: 889-903. CrossRef Medline

Chernyshova Y, Leshchyns'ka I, Hsu SC, Schachner M, Sytnyk V (2011) The neural cell adhesion molecule promotes FGFR-dependent phosphorylation and membrane targeting of the exocyst complex to induce exocytosis in growth cones. J Neurosci 31:3522-3535. CrossRef Medline

Cremer H, Lange R, Christoph A, Plomann M, Vopper G, Roes J, Brown R, Baldwin S, Kraemer P, Scheff S, Barthels D, Rajewsky K, Wille W (1994) Inactivation of the N-CAM gene in mice results in size reduction of the olfactory bulb and deficits in spatial learning. Nature 367:455-459. CrossRef Medline

Cremer H, Chazal G, Carleton A, Goridis C, Vincent JD, Lledo PM (1998) Long-term but not short-term plasticity at mossy fiber synapses is impaired in neural cell adhesion molecule-deficient mice. Proc Natl Acad Sci U S A 95:13242-13247. CrossRef Medline

Crossin KL, Krushel LA (2000) Cellular signaling by neural cell adhesion molecules of the immunoglobulin superfamily. Dev Dyn 218:260-279. CrossRef Medline

Cunningham BA, Hemperly JJ, Murray BA, Prediger EA, Brackenbury R, Edelman GM (1987) Neural cell adhesion molecule: structure, immunoglobulin-like domains, cell surface modulation, and alternative RNA splicing. Science 236:799-806. CrossRef Medline

Di Cristo G, Wu C, Chattopadhyaya B, Ango F, Knott G, Welker E, Svoboda K, Huang ZJ (2004) Subcellular domain-restricted GABAergic innervation in primary visual cortex in the absence of sensory and thalamic inputs. Nat Neurosci 7:1184-1186. CrossRef Medline

Di Cristo G, Chattopadhyaya B, Kuhlman SJ, Fu Y, Bélanger MC, Wu CZ, Rutishauser U, Maffei L, Huang ZJ (2007) Activity-dependent PSA expression regulates inhibitory maturation and onset of critical period plasticity. Nat Neurosci 10:1569-1577. CrossRef Medline

Ditlevsen DK, Povlsen GK, Berezin V, Bock E (2008) NCAM-induced intracellular signaling revisited. J Neurosci Res 86:727-743. CrossRef Medline

Dityatev A, Dityateva G, Sytnyk V, Delling M, Toni N, Nikonenko I, Muller D, Schachner M (2004) Polysialylated neural cell adhesion molecule promotes remodeling and formation of hippocampal synapses. J Neurosci 24:9372-9382. CrossRef Medline

Doherty P, Cohen J, Walsh FS (1990a) Neurite outgrowth in response to transfected N-CAM changes during development and is modulated by polysialic acid. Neuron 5:209-219. CrossRef Medline

Doherty P, Fruns M, Seaton P, Dickson G, Barton CH, Sears TA, Walsh FS (1990b) A threshold effect of the major isoforms of NCAM on neurite outgrowth. Nature 343:464-466. CrossRef Medline

Fujimoto I, Bruses JL, Rutishauser U (2001) Regulation of cell adhesion by polysialic acid. Effects on cadherin, immunoglobulin cell adhesion molecule, and integrin function and independence from neural cell adhesion molecule binding or signaling activity. J Biol Chem 276:31745-31751. CrossRef Medline

Hata K, Polo-Parada L, Landmesser LT (2007) Selective targeting of different neural cell adhesion molecule isoforms during motoneuron myotube synapse formation in culture and the switch from an immature to mature form of synaptic vesicle cycling. J Neurosci 27:14481-14493. CrossRef Medline

He Q, Meiri KF (2002) Isolation and characterization of detergent-resistant microdomains responsive to NCAM-mediated signaling from growth cones. Mol Cell Neurosci 19:18-31. CrossRef Medline

Hildebrandt H, Muhlenhoff M, Weinhold B, Gerardy-Schahn R (2007) Dissecting polysialic acid and NCAM functions in brain development. J Neurochem 103 [Suppl 1]:56-64. CrossRef

Hildebrandt H, Mühlenhoff M, Gerardy-Schahn R (2010) Polysialylation of NCAM. Advances in experimental medicine and biology 663:95-109. CrossRef Medline

Holmgren C, Harkany T, Svennenfors B, Zilberter Y (2003) Pyramidal cell communication within local networks in layer $2 / 3$ of rat neocortex. J Physiol 551:139-153. CrossRef Medline

Huang ZJ, Kirkwood A, Pizzorusso T, Porciatti V, Morales B, Bear MF, Maffei L, Tonegawa S (1999) BDNF regulates the maturation of inhibition and the critical period of plasticity in mouse visual cortex. Cell 98:739-755. CrossRef Medline

Jurd R, Tretter V, Walker J, Brandon NJ, Moss SJ (2010) Fyn kinase contributes to tyrosine phosphorylation of the $\mathrm{GABA}(\mathrm{A})$ receptor gamma2 subunit. Mol Cell Neurosci 44:129-134. CrossRef Medline

Kleene R, Cassens C, Bähring R, Theis T, Xiao MF, Dityatev A, SchaferNielsen C, Döring F, Wischmeyer E, Schachner M (2010) Functional consequences of the interactions among the neural cell adhesion molecule NCAM, the receptor tyrosine kinase TrkB, and the inwardly rectifying K+ channel KIR3.3. J Biol Chem 285:28968-28979. CrossRef Medline

Korshunova I, Novitskaya V, Kiryushko D, Pedersen N, Kolkova K, Kropotova E, Mosevitsky M, Rayko M, Morrow JS, Ginzburg I, Berezin V, Bock E (2007) GAP-43 regulates NCAM-180-mediated neurite outgrowth. J Neurochem 100:1599-1612. CrossRef Medline

Krämer EM, Klein C, Koch T, Boytinck M, Trotter J (1999) Compartmentation of Fyn kinase with glycosylphosphatidylinositol-anchored molecules in oligodendrocytes facilitates kinase activation during myelination. J Biol Chem 274:29042-29049. CrossRef Medline

Kullmann DM (2011) Interneuron networks in the hippocampus. Curr Opin Neurobiol 21:709-716. CrossRef Medline

Lewis DA, Hashimoto T, Volk DW (2005) Cortical inhibitory neurons and schizophrenia. Nat Rev Neurosci 6:312-324. CrossRef Medline

Luscher B, Shen Q, Sahir N (2011) The GABAergic deficit hypothesis of major depressive disorder. Mol Psychiatry 16:383-406. CrossRef Medline

Maness PF, Schachner M (2007) Neural recognition molecules of the immunoglobulin superfamily: signaling transducers of axon guidance and neuronal migration. Nat Neurosci 10:19-26. CrossRef Medline

Markram H, Toledo-Rodriguez M, Wang Y, Gupta A, Silberberg G, Wu C (2004) Interneurons of the neocortical inhibitory system. Nat Rev Neurosci 5:793-807. CrossRef Medline

Morales B, Choi SY, Kirkwood A (2002) Dark rearing alters the development of GABAergic transmission in visual cortex. J Neurosci 22:80848090. Medline

Muller D, Djebbara-Hannas Z, Jourdain P, Vutskits L, Durbec P, Rougon G, Kiss JZ (2000) Brain-derived neurotrophic factor restores long-term potentiation in polysialic acid-neural cell adhesion molecule-deficient hippocampus. Proc Natl Acad Sci U S A 97:4315-4320. CrossRef Medline

Muller D, Mendez P, Deroo M, Klauser P, Steen S, Poglia L (2010) Role of NCAM in spine dynamics and synaptogenesis. Adv Exp Med Biol 663: 245-256. CrossRef Medline

Niethammer P, Delling M, Sytnyk V, Dityatev A, Fukami K, Schachner M (2002) Cosignaling of NCAM via lipid rafts and the FGF receptor is required for neuritogenesis. J Cell Biol 157:521-532. CrossRef Medline

Noble M, Albrechtsen M, Møller C, Lyles J, Bock E, Goridis C, Watanabe M, Rutishauser U (1985) Glial cells express N-CAM/D2-CAM-like polypeptides in vitro. Nature 316:725-728. CrossRef Medline

Pereira DB, Chao MV (2007) The tyrosine kinase Fyn determines the localization of TrkB receptors in lipid rafts. J Neurosci 27:4859-4869. CrossRef Medline

Persohn E, Pollerberg GE, Schachner M (1989) Immunoelectron-microscopic localization of the $180 \mathrm{kD}$ component of the neural cell adhesion molecule N-CAM in postsynaptic membranes. J Comp Neurol 288:92-100. CrossRef Medline

Pillai-Nair N, Panicker AK, Rodriguiz RM, Gilmore KL, Demyanenko GP, Huang JZ, Wetsel WC, Maness PF (2005) Neural cell adhesion molecule-secreting transgenic mice display abnormalities in GABAergic interneurons and alterations in behavior. J Neurosci 25:4659-4671. CrossRef Medline

Polo-Parada L, Bose CM, Landmesser LT (2001) Alterations in transmission, vesicle dynamics, and transmitter release machinery at NCAMdeficient neuromuscular junctions. Neuron 32:815-828. CrossRef Medline

Polo-Parada L, Bose CM, Plattner F, Landmesser LT (2004) Distinct roles of different neural cell adhesion molecule (NCAM) isoforms in synaptic maturation revealed by analysis of NCAM $180 \mathrm{kDa}$ isoform-deficient mice. J Neurosci 24:1852-1864. CrossRef Medline

Ponimaskin E, Dityateva G, Ruonala MO, Fukata M, Fukata Y, Kobe F, Wouters FS, Delling M, Bredt DS, Schachner M, Dityatev A (2008) Fibroblast 
growth factor-regulated palmitoylation of the neural cell adhesion molecule determines neuronal morphogenesis. J Neurosci 28:8897-8907. CrossRef Medline

Puchkov D, Leshchyns'ka I, Nikonenko AG, Schachner M, Sytnyk V (2011) NCAM/spectrin complex disassembly results in PSD perforation and postsynaptic endocytic zone formation. Cereb Cortex 21:2217-2232. CrossRef Medline

Rafuse VF, Landmesser L (1996) Contractile activity regulates isoform expression and polysialylation of NCAM in cultured myotubes: involvement of $\mathrm{Ca}^{2+}$ and protein kinase C. J Cell Biol 132:969-983. CrossRef Medline

Rafuse VF, Polo-Parada L, Landmesser LT (2000) Structural and functional alterations of neuromuscular junctions in NCAM-deficient mice. J Neurosci 20:6529-6539. Medline

Somogyi P, Klausberger T (2005) Defined types of cortical interneurone structure space and spike timing in the hippocampus. J Physiol 562: 9-26. Medline

Somogyi P, Tamás G, Lujan R, Buhl EH (1998) Salient features of synaptic organisation in the cerebral cortex. Brain Res Brain Res Rev 26:113-135. CrossRef Medline

Stoppini L, Buchs PA, Muller D (1991) A simple method for organotypic cultures of nervous tissue. J Neurosci Methods 37:173-182. CrossRef Medline

Stork O, Welzl H, Cremer H, Schachner M (1997) Increased intermale aggression and neuroendocrine response in mice deficient for the neural cell adhesion molecule (NCAM). Eur J Neurosci 9:1117-1125. CrossRef Medline
Stork O, Welzl H, Wotjak CT, Hoyer D, Delling M, Cremer H, Schachner M (1999) Anxiety and increased 5-HT1A receptor response in NCAM null mutant mice. J Neurobiol 40:343-355. CrossRef Medline

Sytnyk V, Leshchyns'ka I, Nikonenko AG, Schachner M (2006) NCAM promotes assembly and activity-dependent remodeling of the postsynaptic signaling complex. J Cell Biol 174:1071-1085. CrossRef Medline

Tamás G, Buhl EH, Somogyi P (1997) Fast IPSPs elicited via multiple synaptic release sites by different types of GABAergic neurone in the cat visual cortex. J Physiol 500:715-738. Medline

Vawter MP, Usen N, Thatcher L, Ladenheim B, Zhang P, VanderPutten DM, Conant K, Herman MM, van Kammen DP, Sedvall G, Garver DL, Freed WJ (2001) Characterization of human cleaved N-CAM and association with schizophrenia. Exp Neurol 172:29-46. CrossRef Medline

Weinhold B, Seidenfaden R, Röckle I, Muhlenhoff M, Schertzinger F, Conzelmann S, Marth JD, Gerardy-Schahn R, Hildebrandt H (2005) Genetic ablation of polysialic acid causes severe neurodevelopmental defects rescued by deletion of the neural cell adhesion molecule. J Biol Chem 280:42971-42977. CrossRef Medline

Wu X, Fu Y, Knott G, Lu J, Di Cristo G, Huang ZJ (2012) GABA signaling promotes synapse elimination and axon pruning in developing cortical inhibitory interneurons. J Neurosci 32:331-343. CrossRef Medline

Zeng L, D’Alessandri L, Kalousek MB, Vaughan L, Pallen CJ (1999) Protein tyrosine phosphatase alpha (PTPalpha) and contactin form a novel neuronal receptor complex linked to the intracellular tyrosine kinase fyn. J Cell Biol 147:707-714. CrossRef Medline 